\title{
THE CHARTER RIGHT TO COUNSEL: BEYOND MIRANDA
}

\author{
PETER B. MICHALYSHYN*
}

\begin{abstract}
This article critically surveys existing Canadian case law defining the elements of section 10(b) of the Canadian Charter of Rights and Freedoms. The author compares the directions Canadian courts appear to be taking the right to counsel with the approach developed in the United States under the Miranda rule and suggests rationales for extending the Charter right to counsel beyond Miranda.
\end{abstract}

\section{INTRODUCTION}

Section 10(b) of the Canadian Charter of Rights and Freedoms ${ }^{1}$ accords to everyone "the right on arrest or detention to retain and instruct counsel without delay and to be informed of that right."

The Fifth Amendment of the Constitution of the United States, as interpreted by Miranda v. Arizona ${ }^{2}$ provides that: ${ }^{3}$

When an individual is taken into custody or otherwise deprived of his freedom by the authorities in any significant way ... he must be warned prior to questioning that he has the right to remain silent, that anything he says can be used against him in a court of law, that he had the right to the presence of an attorney and that if he cannot afford an attorney one will be appointed for him prior to any questioning if he so desires ...

Of the two rights to counsel it has been said that "Section 10(b) ... enacts for the first time in Canada the rule laid down in the United States in Miranda v. Arizona . . ",4 But in fact the Charter right to counsel only superficially resembles the Miranda rule, and it will be seen that resort to American case law has thus far only diminished the potential of the Canadian right. Little is to be gained in the Charter by the application of Miranda practices. But much can be gained by the application of the principles underlying the Miranda decision, and in a study of where the United States Supreme Court erred in attempting to give effect to those principles.

A model of an effective right to counsel thus emerges. Compared to what now exists, it is argued that an effective right to counsel in Canada particularly requires (1) a realistic interpretation of when an individual is detained; (2) a sincere effort by the state to ensure that the individual is informed of the right to counsel; and (3) an equally sincere effort by the state to ensure that the right is waived with full knowledge and appreciation of the consequences. Pivotal to these efforts is the mandatory contact with counsel in the pre-trial stage of the criminal process and the inadmissibility of evidence obtained prior to such contact.

- Law Student, University of Alberta. This article won first prize in the Alberta Law Review William Morrow Essay Contest, 1986.

1. As enacted in Canada Act 1982 (U.K.), c. 11.

2. 384 U.S. 436,86 S. Ct. 1602, 16 L.Ed 2d. 694 (1966).

3. Supra n. 2 at 479.

4. P. Hogg, Constitutional Law in Canada (2nd ed. 1985) 758. 


\section{THE PURPOSE OF THE RIGHT TO COUNSEL ${ }^{5}$}

The purposive approach to Charter interpretation is the key to unlocking the potential of the Charter right to counsel. In $R$. v. Therens, ${ }^{6}$ the Supreme Court of Canada's first s. 10(b) decision, the court little more than restated the section itself: "The purpose of s. 10(b) of the Charter is to ensure that in certain situations a person is made aware of the right to counsel and is permitted to retain and instruct counsel without delay""

The Supreme Court of Canada's second s. 10(b) decision went much farther in defining the purpose of the right to counsel. In Clarkson v. The Queen ${ }^{8}$ Wilson J. stated that "This right, as entrenched in s. 10(b) of the Canadian Charter of Rights and Freedoms, is clearly aimed at fostering the principles of adjudicative fairness,", and later, ". . . the purpose of the right, as indicated by each of the members of the court in Therens, supra, is to ensure that the accused is treated fairly in the criminal process." 10

The question left unanswered even in Clarkson is this: what purpose itself is served by conferring the right to be informed, and the right to be treated fairly in the criminal process? The answer, it is submitted, is the same answer reached by the United States Supreme Court in Miranda. The American court found that the right to counsel serves two fundamental purposes: it first protects the inviolability of the individual's dignity and free will, and it second protects the integrity of the adversary system of justice by ensuring the individual's rights at trial are not prejudiced by ignorance of his rights before trial. Thus in the United States the right to counsel ensures that the individual facing custodial interrogation (in Canada we would substitute "arrest or detention") is informed of his rights so as to make a "free and rational choice whether to incriminate

5. Hunter v. Southam (1984) 14 C.C.C. (3d) 97, 11 D.L.R. (4th) 641, [1984] 2 S.C.R. 145, 2 C.P.R. (3d) 1, 41 C.R. (3d) 97, [1984] 6 W.W.R. 577, 55 N.R. 241, 33 Alta. L.R. (2d) 193, 55 A.R. 291, 27 B.C.L.R. 297, 9 C.R.R. 355, per Dickson J. (as he then was), stating that the key to interpreting a Charter provision is determining its purpose.

6. [1985] 1 S.C.R. 613, 45 C.R. (3d) 97, [1985] 4 W.W.R. 286, 38 Alta. L.R. (2d) 99, 32 M.V.R. 153, 18 C.C.C. (3d) 481, 18 D.L.R. (4th) 655, 13 C.R.R. 193, 40 Sask. R. 122, 59 N.R. 122.

7. Supra n. 6 at 624 S.C.R., per Lamer J. Many lower courts in addition to Therens have commented on purpose. See, for example, Scollin J. in R. v. Nelson (1982) 32 C.R. (3d) 256 at 262 (Man. Q.B.): "The essence of s. 10(b) of the Charter is the guarantee of information, so that an early opportunity to make a reasoned choice is available to the accused: the essence of the provision is opportunity ... The purpose of making the accused aware of his right is so that he may decide; and that means he should have a fair opportunity to consider whether he wishes to resort to his right." Paradis Prov. Ct. J. in R. v. Copley (unreported, Dec. 17, 1982) stated the purpose is "to ensure that, when dealing with the police and facing possible criminal charges, all individuals, not only those who are aggressive, knowledgeable or streetwise, can make an informed decision:" (quoted in R. v. Bento (1983) 27 M.V.R. 71 at 82). And Morden J.A. in R. v. Kelly (1985) 17 C.C.C. (3d) 419 (Ont. C.A.) stated ". . . the relevant interest protected . . . is that of not prejudicing one's legal position by something said or done without, at least, the benefit of legal advice"' (at 424). Stevenson J.A. in $R$. v. Rackow (1986) 47 Alta. L.R. 319 at 325 (C.A.) states "The interest that the section protects, as Kelly notes, it that of not prejudicing one's legal position by something said or done without the benefit of advice, or, I might say, the opportunity to obtain advice"

8. [1986] 1 S.C.R. 383, (1986) 25 C.C.C. (3d) 207, 16 W.C.B. 454. Hetherington J.A. in $R$. v. Jacobs (1987) 48 Alta. L.R. (2d) 81 at 87 (C.A.) favorably cites Wilson J. on the purpose of the right to counsel.

9. Supra n. 8 at 394 S.C.R.

10. Supra n. 8 at 396 S.C.R. 
himself." In short, the right to counsel ensures, in certain well-defined circumstances, the individual's right against self-incrimination. ${ }^{12}$

Canada's courts have acknowledged the existence of a right against selfincrimination ${ }^{13}$ in pre-trial proceedings. Beetz J. in Horvath v. The Queen ${ }^{14}$ stated that ". . . the basic reason [to reject an improperly obtained confession] is the accused's absolute right to remain silent either completely or partially and not to incriminate himself unless he wants to."'15

Unlike the United States, however, in Canada no affirmative right against self-incrimination exists ${ }^{16}$ outside of a criminal courtroom. ${ }^{17}$ Thus the Ontario Court of Appeal in $R$. v. Esposito ${ }^{18}$ stated that although everyone has the "deeply rooted"

11. M. Gardner, "The Emerging Good Faith Exception to the Miranda Rule - A Critique" 35 Hastings L. J. 429 (1984) at 475. After stating its purpose, the United States Supreme Court in Miranda set out what measures it thought would protect the individual's rights and ensure respect for the adversarial system. Chief Justice Earl Warren, writing the majority judgment in Miranda, recognized that the adversarial process did not begin in the courtroom, but the moment police used their authority to begin collecting evidence for the state's case at trial. He also recognized that the environment of police custody was inherently coercive. "An individual swept from familiar surroundings into police custody, surrounded by antagonistic forces, and subjected to the techniques of persuasion described above cannot be otherwise than under compulsion to speak." (384 U.S. 436 at 461 ).

12. There is misunderstanding about the primacy placed on the right against self-incrimination in Miranda. Crown prosecutor Bruce Duncan of Calgary in "Clarkson: Some Unanswered Questions" (1986) 50 C.R. (3d) 305, suggests that deterrance of police misconduct is the primary reason for a right to counsel at detention. Esson J.A. in $R$. v. Strachan (1986) 49 C.R. (3d) 289 (B.C.C.A.) discusses Miranda and similarly concludes that a significant factor in Miranda was "an assumption that an inherent lack in integrity in policy required strong deterrant measures." (315 C.R.) Both Duncan and Esson J.A. argue that given the historical absence of police misconduct in Canada, there is no need for a Miranda style of right. For a contrary view of the police record in Canada, see generally Ken Chasse, "Charter Exclusion - Causation, Nexus and Disrepute" (1986) 21 C.R.R. 227, and Ratushny, infra n. 21.

Justice William Rehnquist (as he then was) of the United States Supreme Court has also interpreted Miranda as primarily a deterrant to police excesses rather than a protection of individual liberty and respect for the adversarial system: New York v. Quarles 104 S. Ct. 2626 (1984); also see Harris v. New York 401 U.S. 222 (1971); Michigan v. Tucker 417 U.S. 433 (1974); Moran v. Burbine 89 L. Ed. 2d. 410 (1985); Oregon v. Elstad 84 L. Ed. 2 d. 222 (1985). However, it is submitted that Rehnquist J's interpretation is incorrect, as is persuasively argued by Gardner (supra n. 11); even conservative commentators grudgingly acknowledge that the right is based on the right against self-incrimination: see, for example, William Tucker, "True Confessions: The Long Road Back from Miranda" National Review, 18 October, 1985, p. 28. See also the dissent of Brennan J. in Oregon v. Elstad, supra at 238, in which he states "... the Court has engaged of late in a studied campaign to strip the Miranda decision piecemeal and to undermine the rights Miranda sought to secure:"

Finally, see also the recent debate over Miranda between Caplan, "Questioning Miranda," 38 Vand. L.R. 1417 (1985) and a reply by White, "Defending Miranda: A reply to Professor Caplan" 39 Vand. L.R. 1 (1986).

13. And the corollary right to remain silent.

14. (1979) 44 C.C.C. (2d) 385,7 C.R. (3d) 97 (S.C.C.).

15. Supran. 14 at 430 C.C.C.

16. That is, no right to be informed of the right to silence. See generally, E. Ratushny, "The Role of the Accused in the Criminal Process," in Tarnopolsky and Beaudoin, eds. The Canadian Charter of Rights and Freedoms: Commentary (1982).

17. Section 11 (c) of the Charter guarantees the right against being compelled to testify against oneself in a criminal trial.

18. (1985) 49 C.R. (3d) 193, 53 O.R. (2d) 356 (Ont. C.A.) (leave to appeal to the Supreme Court of Canada refused, O.R. loc cit).

19. Supra n. 18 per Martin J.A. at 200 C.R. 
police questioning, there is no obligation on police, before or after arrest or detention, to advise an individual that he has that right.

This seeming contradiction - the illogic of conferring an affirmative right against self-incrimination at trial but not during interrogation - has long been recognized in Canada. ${ }^{20}$ As one observer has noted, "There is a hypocrisy to a system which defines a person's rights and obligations in its laws and then depends upon the ignorance of those laws [during interrogation] to ensure that they are laregly ineffective in their practical application."21

It is submitted that the purposive interpretation of the Charter logically and inevitably will lead Canada's courts to follow Miranda and embrace the individual's right against self-incrimination as the very basis of the right to counsel. This is not to argue, however, that the adoption of the Miranda principles should be followed by the adoption of Miranda practices. For those practices, which are the subject of the balance of this discussion, have largely failed to confer the right they were sought to protect.

\section{THE RIGHT TO COUNSEL: MIRANDA AND SECTION 10(b)}

\section{A. WHERE THE RIGHT STARTS - CUSTODIAL INTERROGATION/ARREST OR DETENTION}

\section{Miranda}

After extensive consideration of the nature of police interrogation, the Miranda court concluded that "custodial interrogation" - questioning on arrest or at any time the individual was significantly deprived of his freedom - was inherently compulsive. As a result the court imposed a presumption that statements made in response to questioning while in custody were obtained coercively and would be inadmissable in court unless the state showed the individual had been accorded his Miranda rights. ${ }^{22}$

The Miranda court stopped short of suggesting that an individual who entered a police station voluntarily and confessed would be victimized by the absence of Miranda warnings. ${ }^{23}$ However, a later court decided in Ore. v. Mathiason ${ }^{24}$ that custodial interrogation would not exist if an individual voluntarily accompanied police to a detachment, provided the individual was not under arrest and would be free to leave at any time. ${ }^{25}$

20. Ratushny, supra n. 16; also see Canadian Civil Liberties Association "The Effective Right to Counsel in Ontario Criminal Cases,' brief presented to Ontario Attorney General, Nov. 30, 1972.

21. E. Ratushny, Self Incrimination in the Criminal Process (1979) 252-253.

22. Supra n. 2 at 478.

23. Supra n. 2 at 478 . Miranda also stated that warnings were not necessary for general 'on-thescene' questioning (supra n. 2 at 477) nor where there was a mere curtailment of freedom, such as in a routine traffic stop: Berkemer v. McCarty 82 L. Ed. 2 d 317 (1984).

24. 429 U.S. 492 (1976).

25. But evidence that an individual was not free to leave in such circumstances would give rise to the Miranda requirement: Orozco v. Texas: 394 U.S. 324 (1968). 
The United States Supreme Court's latest interpretation of "custodial interrogation" came in California v. Beheler ${ }^{26}$ The court in that case set out a more restrictive test, stating that custody would not exist when the individual was merely a suspect, even though it was clear that questioning by police was intended to produce incriminating responses. The court held that ". . . the ultimate inquiry is whether there is a 'formal arrest or restraint on freedom of movement' of the degree associated with a formal arrest."27

\section{Section 10(b)}

Section 10(b) rights accrue "on arrest or detention". It is well settled that an arrest occurs when an individual is physically taken into custody, or when he is told he is under arrest and acquiesces. ${ }^{28}$

The contentious area is detention. As an observer has recently noted, “. . . detention short of arrest is the point at which the legal rights of an individual being questioned come into direct conflict with the use of interrogation as a viable investigative procedure. Here the individual has the greatest need to obtain and instruct counsel without delay and enforcement officials have the strongest aversion to the intrusion of counsel."29

The emerging definition of detention by Canada's courts potentially transcends the American definition in Mathiason ${ }^{30}$ and Beheler ${ }^{31}$ of custodial interrogation. The starting point is Therens. Le Dain, J. on the issue of detention ${ }^{32}$ set out three tests: “. . . in addition to the case of deprivation of liberty by physical constraint [the first test], there is, in my opinion, a detention within s. 10 of the Charter when a police officer ... assumes control over the movement of a person by a demand or direction which may have significant legal consequences and which prevents or impedes access to counsel [the second test] ..." or when there is "psychological compulsion, in the form of a reasonable perception of suspension of freedom of choice [the third test] . .."33

The first two tests are straightforward; they would appear to be equivalent to Miranda's test of actual arrest or significant deprivation of

26. 103 S. Ct. 3517 (1983).

27. Supra n. 26 at $3519-20$.

28. R. v. Whitfield (1970) 1 C.C.C. 129; Salhany, Canadian Criminal Procedure (4th ed. 1984) 42-43.

29. G.S. Garneau, "The Application of Charter Rights to the Interrogation Process" (1986) 35 U.N.B.L.J. 35 .

30. Supran. 24.

31. Supra n. 26.

32. Dickson C.J.C., McIntyre and Lamer J.J. concurring.

33. Supra $\mathrm{n} .6$ at 504-505 C.C.C. It has been held that a new detention may arise when an individual is detained. See $R$. v. Jacobs, supra n. 8. 
freedom..$^{34}$ It is Le Dain J's psychological compulsion test that stands to push Canada beyond the current American test. Indeed, Tarnopolsky J.A. in an obiter comment from $R$. v. Bazinet ${ }^{35}$ stated that the test in the American case of Beheler - restraint on freedom of movement of the degree associated with formal arrest - ". . . is probably a narrower test than that suggested by Le Dain J. in Therens." ${ }^{36}$

Le Dain J's psychological compulsion test is based on the presumption that "it is not realistic, as a general rule, to regard compliance with a demand or direction by a police officer as truly voluntary."37 It is clearly obiter to the decision in Therens, but the underlying principle is supported by the unanimous court in $R$. v. Dedman ${ }^{38}$ where again Le Dain J. for the majority of the Supreme Court of Canada stated that compliance with a police demand or direction should not be regarded as voluntary, but rather as inherently coercive and authoritative.

While the concept of psychological detention was not endorsed explicitly by the balance of the Supreme Court of Canada in Therens, treatment of the concept by various courts of appeal suggests that it is now the prevailing test. Thus, the Alberta Court of Appeal in $R$. v. Ancelet ${ }^{39}$ endorsed the concept that detention may exist in the absence of physical restraint. The court outlined a subjective-objective test for detention: "[An individual] may be detained even in the absence of physical restraint or the threat of application of physical restraint if (1) he believes that the choice to do otherwise does not exist (a subjective test), and (2) his belief is reasonable (an objective test)."'

On the facts of Ancelet, no detention was found when the individual was asked to enter a police vehicle. Nor was the individual found to be detained when he was asked to go to the police station for further questioning and pictures. Hetherington J.A. came to that conclusion apparently based on a

34. A flood of litigation over whether a demand for an ALERT roadside breathalyzer test amounts to detention has produced mixed results. Various courts of appeal have held an ALERT demand amounts to detention. The courts have gone on to state however that the failure to confer the right to counsel is a reasonable limit under s. 1 of the Charter. This is the position taken in $R$. v. Sydney Smith (1987) 74 A.R. 64, (1986) 17 W.C.B. 456 (Alta. C.A.) That reasoning has not been scrutinized by the Supreme Court of Canada, and is open to criticism: see for example J. Falconer, "The ALERT Demand and the Right To Counsel: The Problem with Talbourdet" (1986) 28 Crim. L. Q. 396 and S. Cohen, "Roadside Detentions: ALERT Testing and the Right to Counsel" (1986) 51 C.R. (3d) 34.

35. (1986) 54 O.R. (2d) 129 (Ont. C.A.).

36. Per Tarnopolsky J.A. in Bazinet, supra n. 35 at 142 O.R. Recognizing this, some courts have employed American jurisprudence to impose limits on the emerging definition of detention under the Charter. See, for example, Bazinet, supra n. 35 and Esposito, supra n. 18. In an annotation to Esposito, Don Stuart remarks that "It seems unwise to attempt to restrict the scope of s. 10(b) through importing United States jurisprudence on custody." (1986) 49 C.R. (3d) 194 at 195. See also R. v. Neale (1986) 71 A.R. 337 (C.A.) where the court warns, in a different context, against "simplistic adoptions by reference" of American jurisprudence (at 341).

37. Supra n. 6 at 505 C.C.C. per Le Dain J.

38. (1985) 20 C.C.C. (3d) 97 at 116 (S.C.C.).

39. (1986) 70 A.R. 263, 45 Alta. L.R. (2d) 193), [1986] 4 W.W.R. 761,17 W.C.B. 20 , leave to appeal to S.C.C. denied: January 30, 1987 Bulletin of Proceedings taken in the Supreme Court of Canada, 72.

40. Supra n. 39 at 267 A.R. 
conversation between the police and the individual during which the police made it clear the individual did not have to accompany them to the station. The officer also indicated that the individual could have a lawyer present if he wished. ${ }^{41}$

A somewhat different test for detention emerged in Bazinet ${ }^{42}$ in which Tarnopolsky J.A. held that psychological compulsion rested upon two requirements: "(1) a 'demand or direction' [by police] in response to which (2) 'the person concerned submits or acquiesces in the deprivation of liberty and reasonably believes that the choice to do otherwise does not exist." ${ }^{43}$ Tarnopolsky J.A. concluded that police must make an authoritative request, order or command to an individual, rather than a mere request, before the first requirement would be satisfied. In Bazinet, the individual volunteered to accompany his interrogators to the police station. He did so, however, after police visited his home and requested to ask him some questions. Tarnopolsky J.A. distinguished an admittedly compulsive "demand or direction" from a mere request and held that the latter would not give rise to detention. As to the second requirement, Tarnopolsky J.A. found no evidence, subjective or objective, that the individual "actually felt that he was being deprived of his liberty and had no choice but to submit ...".44

In Esposito ${ }^{45}$ Martin J.A. held that psychological detention would be found only if an individual showed he reasonably believed his freedom was restrained. ${ }^{45}$ In that case, no detention existed when the individual was questioned by police late at night in his own home. During that questioning, the individual, a gas station attendant, was confronted with 18 fraudulent invoices for gas purchases. Some of the invoices were initialled, and of those, some bore the individual's initials. The individual told the police he had made out the invoices but added that he had not signed them. He was then arrested and read his s. 10(b) rights. He was eventually convicted on the basis of the statement made prior to arrest. Martin J.A. found no evidence of compulsive questioning prior to arrest, nor any

41. Supra n. 39 at 268 A.R.

42. Supra n. 35.

43. Supra n. 35 at 139 O.R.

44. Supra n. 35 at 140 O.R. Bazinet appears to have been followed in R. v. Faul (unreported, July 9, 1986; summarized in Lawyers Weekly Digest 19 September, 1986 (Ont. Prov. Ct.)) where a request to perform sobriety tests in the early stages of an impaired driving investigation did not amount to a demand or direction. Batten, Prov. Ct. J. acknowledged that the police investigators exhibited an air of authority and that the possibility existed that the accused experienced psychological coercion and felt he had no choice but to submit. The court held however that there was no evidence that the accused indeed felt compelled to submit.

A different view of a request for sobriety tests was taken in $R$. v. Duval (1986) 17 W.C.B. 120 (Ont. Prov. Ct.), which held the individual was detained after the request to perform tests.

45. Supra n. 18.

46. Supra n. 18 at 208 C.R. 
evidence that the accused felt subjectively or objectively that his freedom was restrained..$^{47}$

\section{Analysis}

The interpretations of detention given by the courts of appeal are ultimately unsatisfactory. The first weakness is the attempt to distinguish between a "demand" and a "request." It is submitted that a police request - particularly when made to an individual unaccustomed to dealing with police - will very often be treated as a demand or direction. As McLellan, Co. Ct. J. stated in R. v. Carroll, ${ }^{48}$ "Most lay people are not aware of the common law restraints which are placed upon peace officers during an investigation of an offense.' One may ask if it is realistic to say that an individual does not feel compelled to obey when police knock on his door at home, as in Bazinet, and request that he come to the police station for questioning. Is it realistic to say that an individual unaccustomed to dealing with police can freely refuse a police request to perform sobriety tests especially absent advice that he has nothing to lose by so refusing? Is it realistic to say that an individual will feel genuinely free to leave when he is being questioned by police in a closed room at a police detachment? As Professor Stuart noted in a comment on Bazinet, "The court seems curiously impervious to the coercive realities behind a 'request' by a police officer to answer questions when it is clear to the person questioned that he is a suspect." 49

The second weakness in the decisions by the courts of appeal on psychological detention is their application of the subjective/objective test for compulsion. Is it not largely irrelevant whether an individual feels subjectively compelled to incriminate himself? The absence of such subjective fears may well be attributed to skillful police technique or to the dullness or innocence of the individual himself. Surely the more important and revealing side of the two-pronged test is the objective aspect. It is submitted that the question to be asked in all cases is whether objectively police conduct or questioning is intended to elicit from an individual evidence that can be used against him or which will lead to further evidence being adduced which can be used against him. Such a test would not apply

47. A companion case to Esposito is the Manitoba Court of Appeal's decision in $R$. v. Smith (1985) 49 C.R. (3d) 210 (Man. C.A.). At 9:15 p.m., police called upon the accused and a female house-mate. The police stated they were investigating a death of an infant earlier that day. They invited the two individuals to accompany them to police headquarters "to discuss the matter further.' The individuals complied. One individual was interviewed in a room, with the door closed, for about a half hour. After interviewing the second individual, police returned to the room in which the first had remained. He was then formally charged with homicide and read his s. 10(b) rights. The individual said he understood the rights and made no effort to exercise them. He then made an incriminating statement. The Court of Appeal found there was no detention prior to the individual's second interview. The individual had attended the police detachment voluntarily; he had no reason to believe he was a suspect. Nor did the police, it was held, believe he was a suspect at that time. Further, it was found as a fact that during and after the first interview, and up to the time immediately prior to the second interview, the individual would have been free to leave the detachment had he wished to do so.

48. (1986) 70 N.S.R. (2d) 198 at 203.

49. D. Stuart, "Annotation," (1986) 51 C.R. (3d) 140. See also n. 53 and accompanying text for one definition of "questioning." 
to evidence that results innocently, either from police "on the scene" questioning or from a spontaneous outburst by an individual. It may argued that such a test transcends Le Dain J's definition of psychological compulsion, to wit, "a reasonable perception of freedom of choice." However, it is submitted that Le Dain J's definition is inadequate, if at all, to the extent that it does not acknowledge the infinite number of ways that the intentional acts of persons in authority can result in a compulsive environment and in a denial of real choice for an individual in deciding whether to incriminate himself.

Applying the test, as an example, to the result in Ancelet, the result of the case becomes less clear. No detention was found in large part because police told the individual he did not have to accompany them to a police station for questioning. Applying the subjective test, the individual did not feel detained. A different result could obtain however from applying the objective test rigorously. For example, the police in the same conversation before leaving for the police station repeatedly told the individual that he could have a lawyer present during questioning. It would thus appear that whatever the individual may have thought, the police were aware of his precarious legal position. At the very least, the police were likely aware that their subsequent questioning could well elicit incriminating evidence, as it ultimately did. On these facts and applying the proposed test, the individual in Ancelet was very likely detained..$^{50}$

In conclusion, the leading cases set an unrealistic standard for detention. Detention must exist whenever an individual in a coercive police environment risks incriminating himself. A realistic application of the subjective/ objective test would acknowledge the inherently involuntary nature of purposeful police conduct and questioning. It would also recognize that all

50. In Esposito police sat in the individual's living room and confronted him with evidence of forged invoices. Is it realistic to say that the police did not suspect the individual of having committed an of fense? Is it realistic to say that police were not merely fishing for a confession or some other incriminating evidence?

The problem was further illustrated in a recent series of cases involving wildlife statute of fenses. In R. v. Roberts and Atkinson (1986) 22 C.R.R. 252 (Man. Prov. Ct.), Enns, Prov. Ct. J. stated that the right to counsel should not be interpreted "so as to countenance a practice whereby a confession, if made early in an encounter between an informed peace officer and an accused, is automatically admissable even though the accused elects to remain silent as soon as he is informed about his rights." (at 258). Similarly, in R. v. Morgan (1986) 22 C.R.R. 164 (B.C. Prov. Ct.), Smyth, Prov. Ct. J. stated that on the facts, ". . . the defendant's detention had gone beyond what was justified to determine if he was apparently conducting himself lawfully and had come to have no other real purpose than to build a case against him." (at 170)

In Re United States of America and Randazzo (1986) 22 C.R.R. 43 (B.C.S.C.), after asking the accused several questions about her dead husband and asking her to go to the police station to write out a statement, the court concluded the police officer had gone beyond mere information gathering. "The constable admits that the woman was then a suspect [during questioning] and he intended to take an inculpatory statement from her if the circumstances led to that:" (at 46)

Finally, see R. v. Savard (1986) 17 W.C.B. 120 (Ont. D.C.); R. v. Paschal (1986) 74 N.S.R. (2d) 184 (N.S.T.D.); R. v. Barsanti(1986) 17 W.C.B. 432 (Ont. D.C.); R. v. Spencer (1986) 17 W.C.B. 433 (N.B.C.A.); and R. v. Belliveau (1986) 9 C.R.D. $800-03$ (N.B.C.A.). 
police conduct is not similarly purposeful. Thus, general 'on the scene' or 'informational' questioning would not give rise to detention."

\section{B. RETAINING AND INSTRUCTING COUNSEL}

\section{Miranda}

(a) The right to be Informed

Miranda confers the right to be informed of the following: the right to silence and the right to counsel, the right to have a lawyer present and the right to have counsel appointed if the individual cannot afford a lawyer. Upon being informed of the right, the individual must decide whether to invoke it or to waive it. s2 $^{2}$

\section{(b) When the Right is Waived}

Any waiver of the right must be made "knowingly and intelligently." Typically this test will be met by evidence that the individual understands the right and voluntarily waives it; in many cases a signed waiver is secured, although Miranda itself secures no such right. ${ }^{33}$ The case of Edwards v. Arizona ${ }^{\text {st }}$ states that a waiver is not found if an individual has invoked the right to counsel, then responds to police questioning. The fact that an individual answers some questions and not others does not imply a waiver. Nor will silence after being read his Miranda rights, followed by an incriminating statement, imply a waiver. Finally, "any evidence that the accused was threatened, tricked or cajoled into a waiver" will invalidate the waiver. ${ }^{s s}$

(c) When the Right is Invoked

If the individual decides not to waive the Miranda rights, police must cease all questioning and allow him to contact a lawyer. ${ }^{56}$ Questioning has been defined as "any words or actions on the part of the police (other than those normally attendant to arrest or custody) that the police should know are reasonably likely to elicit an incriminating response from the suspect." 37 No time limit is imposed on the individual's efforts to retain counsel. Legal aid counsel will be appointed if necessary. Moreover, if counsel for some reason is not available police cannot begin questioning until the individual has expressly waived not only his right to counsel but also his right to silence.

51. It has even been suggested that a sincere dedication to adversarial principles demands that the right to counsel warning be given when the individual voluntarily attends at a police station and makes an unprompted statement: P. Mirfield, Confessions (1985) 157. It should be noted however that the protection in Miranda is against compelled statements and not against wholly voluntary ones: J. Tomkovicz "Standards for Invocation and Waiver of Counsel in Confession Contexts" (1986) 71 Iowa L. Rev. 975 at 989.

52. Supra n. 2 at 478-79.

53. Supra n. 2 at 475-76.

54. 451 U.S. 477 (1981).

55. Supra n. 2 at 475-76.

56. Supra n. 2 at 474.

57. Rhode Island v. Innis 446 U.S. 291 (1979). 


\section{Section $10(b)$}

\section{(a) The Right to be Informed}

Pre-Charter law in Canada recognized the right to retain and instruct counsel but did not confer the right to be informed of that right. The right to be informed was thus a new right under the Charter..$^{58}$ It recognizes that an individual who is detained or under arrest cannot be assumed to know his rights, and that such knowledge is essential..$^{99}$

\section{(i) Special Circumstances}

The right to be informed under the Charter is similar to the right offered by Miranda. Indeed the doctrine of "special circumstances" which has emerged in Canada appears to go further than Miranda. The arch-typical case in Canada is $R$. v. Nelson..$^{60}$ The accused, charged with murder, was read an inexact version of the s. 10(b) warning. Asked if he understood, he replied "Yup, yup." He was then asked questions which elicited incriminating answers. The court held that the responses, "Yup, yup", were insufficient evidence that the individual understood his rights. It held that in the individual's "special circumstances" - he was not read the statutory s. 10 (b) rights, was poorly educated and unsophisticated and had recently been drinking - the police should have gone farther to inform him of his right to counsel. In Nelson that meant that police should have asked if the individual wanted to exercise his right. Had he wished to do so, police should have given him a reasonable opportunity to exercise the right without delay. Absent special circumstances, however, Nelson dictated that police had only to recite the statutory s. 10(b) right, and again, if the right was invoked, to give the individual a reasonable opportunity to exercise it. ${ }^{61}$

58. Once detained, the individual must immediately be informed of the right to counsel (quite apart from being able to exercise the right "without delay"): $R$. v. Rackow (1986) 47 Alta. L.R. (2d) 319 (C.A.). See also R. v. Phillips; R. v. Reid (1986) 44 Alta. L.R. (2d) 190, 69 A.R. 54 (C.A.). However, see also R. v. Kelly ((1985) 17 C.C.C. (3d) 419 (Ont. C.A.), leave to appeal to S.C.C. denied (1986) 65 N.R. 320, where the individual was detained but was also "taking rather wildly" and "screaming and yelling", and a scuffle broke out. The court held that it would have made no sense to recite the individual's s. $10(b)$ rights at this point. Those rights were given the accused at the police station while he was in cells. It was held to be a reasonable delay in the circumstances. The ratio in Kelly was endorsed by Hetherington J.A. in $R$. v. Jacobs, supra n. 8.

59. Thus at least to this extent Canada divests itself of the logic in the important pre-Charter case of Jumaga v. R. [1977] 1 S.C.R. 486, [1976] 3 W.W.R. 637, 34 C.R.N.S. 172, 29 C.C.C. (2d) 269, 68 D.L.R. (3d) 639, 9 N.R. 102 [Man.], that one cannot be denied that which one does not ask for. That logic however seems to remain for the issue of privacy. Several cases have held that an individual does not have a right to privacy unless he asks for it: $R$. v. Fallowfield (1983) 24 M.V.R. 97 (B.C. Co. Ct.); R. v. Huddleston (1984) 34 Sask. R. 68 (Sask. Q.B.). A contrary view of privacy is emerging however which asserts that a failure to provide privacy - whether or not the individual asks for it - is a Charter breach: $R$. v. Falk (1986) 70 A.R. 74 (Alta. C.A.); LePage v. The Queen (1986) 9 C.R.D. $825.40-02$ (N.S.C.A.); R. v. Ginther (Lawyers Weekly Jan. 16, 1987, p. 2 (Sask. C.A.)); R. v. Henry (1986) 17 W.C.B. 282 (N.B.Q.B.); R. v. Rowbottom (1983) 18 M.V.R. 202 (Nfld. Prov. Ct.); Laidlaw v. The Queen (1986) 16 C.R.R. 98 (Ont. Dist. Ct.) and R. v. Johnson (1986) Alta. L.R. (2d) 353, 17 W.C.B. 44 (Alta. Prov. Ct.). See the apparently contrary view in R. v. Hunter (1986) 45 Alta. L.R. (2d) 405 (Alta. C.A.).

60. (1982) 3 C.C.C. (3d) 147, 32 C.R. (3d) 256, 4 C.R.R. 88 (Man. Q.B.).

61. Nelson was followed in the oft-cited s. 10(b) case of R. v. Anderson (1984) 10 C.C.C. (3d) 417, 7 D.L.R. (4th) 306, 45 O.R. (2d) 225, 39 C.R. (3d) 193, 9 C.R.R. 161 (Ont. C.A.). 
The key question under Nelson is what is a special circumstance? Ignorance would appear to be high on the list. Thus in $R$. v. Haniliak, ${ }^{62}$ a special circumstance was the fact that individuals in Northern communities, isolated from the legal world, "require a fuller explanation of their rights when taking a statement, an explanation of their rights and a clearer warning on arrest or detention." 63

In $R$. v. Bento ${ }^{64}$ "special circumstances" dictated that the individuals had a right to an interpreter to be told their rights. Any evidence of "questionable mental capacity" in the individual conferred a duty upon police - as a result of the special circumstance - to ensure the right was understood: Lussa v. The Health Science Centre and Director of Psychiatric Services. ${ }^{65}$

Drunkenness has amounted to a special circumstance and obliges a police officer to take extra steps to communicate the s. 10(b) right: Schmidt v. The Queen. ${ }^{66}$

The "special circumstances" test also applies to whether police are required to repeat the s. 10 (b) right. Normally it would not be necessary to repeat the s. 10 (b) right more than once, although it might be desirable to do so in certain circumstances. Thus it was held that an individual given his rights upon arrest could not expect police to remind or reassure him of the rights upon arrival at a police detachment: $R$. v. Dumas.$^{67} \mathrm{It}$ is worth noting that $R$. v. Charrette ${ }^{68}$ held that it was necessary, even absent special circumstances, for police to repeat the s. $10(\mathrm{~b})$ right when they started questioning the individual an hour after the right was first recited. And in $R$. v. Johnson ${ }^{69}$ it was held that the right should have been repeated when the investigation shifted from a provincial statutory offense to a more serious Criminal Code offense.

Further to being informed of the right, it has been held that a police officer must at least ensure that an individual is conscious when he is read his s. 10(b) right. ${ }^{70}$ Short of special circumstances as laid out in Nelson, an individual could not claim he did not realize "counsel" meant "lawyer": $R$. v. Schlosser."

62. [1985] N.W.T.R. 352 (N.W.T.S.C.).

63. Supra n. 62 at 354.

64. Supra n. 7. See also R. v. Tanguay (1984) 27 M.V.R. 1 (Ont. Co. Ct.) and R. v. Suoboda (1986) 43 Alta. L.R. (2d) 411 (Prov. Ct.).

65. (1984) 9 C.R.R. 350 (Man. Q.B.); see also R. v. Johnny (1985) 13 W.C.B. 53 (B.C.S.C.).

66. (1985) 36 Sask. R. 298, 13 C.R.R. 59 (Sask. Q.B.); see also R. v. Leatherdale (1985) 13 W.C.B. 453 (B.C. Co. Ct.).

67. (1985) 41 Alta. L.R. (2d) 348 (C.A.); see also R. v. Leger (1984) 34 Sask. R. 159 (Sask. Q.B.); $R$. v. Chief(1983) 24 Man. R. (2d) 278 (Co. Ct.); $R$. v. MacDonald (1986) 25 C.C.C. (3d) 572 (N.S.C.A.); R. v. Barlett (1986) 15 W.C.B. 275 (Ont. Dist. Ct.).

68. (1984) 10 C.R.R. 226 (Ont. Dist. Ct.).

69. (1985) 36 M.V.R. 111,20 C.R.R. 9 (N.B.Q.B.).

70. R. v. Simon (1985) 13 C.R.R. 1 (Sask. Q.B.). The individual must also have heard the right being read: $R$. v. Stewart (1985) 7 C.R.D. 825.30-02.

71. (1986) 43 Sask. R. 110 (Sask. Q.B.). See also R. v. Macdonald (1985) 7 C.R.D. 825.30-03. 
In certain circumstances it has been held unnecessary to inform an individual of the right to counsel if he already knew of his rights: $R$. v. Hamilton. ${ }^{2}$ Similarly if an individual already knew of the right, notice by way of a sign posted on the wall would amount to being informed of the right: $R$. v. Ahearn. $^{\text {'3 }}$

The prevailing view has also been that police should recite the actual wording of the s. 10(b) right. Scollin J. in Nelson ${ }^{74}$ stated ". . . I think it invites difficulty from the outset if the accused is not upon his arrest informed as soon as is practicable in exactly the terms enacted ... it is better that [an individual] be confused about what the constitution states rather than confused about what the police say the Constitution states."'? The Alberta Court of Appeal in R. v. Jacobson ${ }^{76}$ however has departed from this view. In Jacobson, Laycraft C.J.A. held in an oral judgment that the statement "Do you want a lawyer?" was a sufficient communication of the right to counsel. The trial judge in Jacobson had held that warning to be insufficient because the individual would not clearly understand the offer was of a "right" to counsel, as opposed to the mere availability of an option. Laycraft C.J.A., in ordering a new trial, stated "We are all agreed that any reasonable person would take from the words spoken here the information that he was now accorded the right to call his lawyer ... No particular formula or wording is required to give notification under $\mathrm{s}$. 10(b) of the Charter." "

\section{(ii) Special Circumstances Rejected}

While the "special circumstances" doctrine seems well established in Canadian law, it is worth noting a line of cases which run counter to the doctrine. The most recent example is the Ontario District Court decision of Menzies v. $R .{ }^{78}$ which purports to breath life into the famous case of $R . v$. Shields. ${ }^{79}$

In Shields, Borins Co. Ct. J. held that the mere recitation of s. 10(b) was meaningless if the police had no affirmative duty - even in the absence of a request for counsel - to indicate how the right might be exercised.

72. (1985) 69 N.S.R. (2d) 226 (Co. Ct.).

73. (1983) 25 M.V.R. 287 (P.E.I.C.A.). However, see a different result in R. v. Dawson (1986) 70 A.R. 12 (Alta. Q.B.).

74. Supra n. 60.

75. Supra n. 60 at 426 C.C.C. (emphasis in original). Scollin J. is of course speaking of an individual facing "special circumstances."

76. (1986) 46 Alta. L.R. (2d) 390 (Alta. C.A.), leave to appeal to S.C.C. denied (1986) Bulletin of Proceedings taken in the Supreme Court of Canada, 1429.

77. Supra n. $\mathbf{7 6}$ at $\mathbf{3 9 2}$. Although it is not clear from the brief oral judgment in Jacobson, the possibility exists that on the facts of the case, the individual was found to be already familiar with the criminal justice system and the "right" to counsel. It is worth noting that the Ontario Court of Appeal in $R$. v. Manninen, infra $n$. 98 held that everyone has the right to be informed completely of the s. $10(\mathrm{~b})$ rights (infra n. 108 and accompanying text).

78. (1986) 51 C.R. (3d) 387 (Ont. Dist. Ct.).

79. (1983) 6 C.R.R. 194, 10 W.C.B. 120 (Ont. Co. Ct.). Shields was expressly disapproved of in Anderson, supra n. 61, but was nevertheless followed in Crossman v. The Queen [1984] 1 F.C. 681,12 C.C.C. (3d) 547 (F.C.T.D.) and in part in Williams, infra n. 82. 
Shields was stated to be the law - and Anderson ${ }^{80}$ was stated to be overruled - in Menzies. Misener Dist. Ct. J. in Menzies relied on the Supreme Court of Canada's decision in Clarkson ${ }^{81}$ to reach the conclusion that police had an obligation to every individual not only to recite the wording of s. 10(b) but also to explain the nature of the right and the consequences of a waiver. In Clarkson the individual was read the s. 10(b) right. She then waived the right. Wilson J. rejected the waiver, arguing that the individual did not have knowledge of the consequences of the waiver. Why did the individual not have that knowledge of the consequences? Clarkson seems to point to the individual's gross intoxication, the absence of which would have validated the waiver. But Misener Dist. Ct. J. stated that Clarkson did not hinge on intoxication. On that basis he came to the inevitable conclusion that something more in every case was required in addition to the recitation of s. 10(b). That something more would be advice on the consequences of waiving the right.

It is worth noting as well a recent split decision of the Alberta Court of Appeal on the sufficiency of informing an individual of the right to counsel and of the exercise of the right. In $R$. v. Williams ${ }^{82}$ Hetherington J.A. invoked Shields in part to conclude that in every case "If the accused in any manner indicates that he would like to retain and instruct counsel, the peace officer is obliged to explain to him how he may do so." ${ }^{83}$ Typically this would amount to being offered a telephone book and being advised of the availability of legal aid counsel. Laycraft C.J.A. and Haddad J.A. agreed with Hetherington J.A.s result but refused to apply her universal rule. The court is thus still square with the "special circumstances" doctrine. Yet Haddad J.A., apparently sympathetic to Hetherington J.A.s view, went on to say that it would be "commendable" Hetherington J.A.'s universal rule. And he added ". . . if a person requests assistance [in how to exercise the right] there is at least a moral obligation on the police to honour that request."'s5

\section{(b) When the Right is Waived}

Just as in Miranda, once the individual is deemed informed of the right to counsel under s. $10(\mathrm{~b})$, he has two choices. He can waive the right or exercise it.

80. Supra n. 61 .

81. Supran. 8.

82. (1986) 48 Alta. L.R. (2d) 68, (1987) 73 A.R. 388 (C.A.). In the case, the individual was informed of his right to counsel but was somewhat equivocal whether he wished to exercise it. Asked if he wanted to make a statement, he said "I know I did something wrong, but I don't want to say too much without counsel:" That amounted to an invocation of the right to counsel, after which police should have desisted from questioning.

See also R. v. Shannon (1986) 17 W.C.B. 350 (N.W.T.S.C.), in which Marshall J. held that given the reality of arrest, an individual may feel he cannot do anything without a police officer's assent, including asking to use a telephone to call counsel.

83. Supra n. 82 at 77.

84. Supra n. 82 at 70.

85. Supra n. 82 at 70 . See also Laycraft C.J.A.s decision in $R$. v. Rogal (unreported, January 8 , $1987 \# 8603-0476 \mathrm{~A}$ (C.A.)), where it was stated in obiter that once the right to counsel is invoked police should provide the individual with a telephone and the appropriate directories. Unlike Williams in Rogal the individual never requested to exercise his right to counsel. 
The early Charter case of Nelson stated that only in "special circumstances" would it be necessary for police to inquire, after reciting the right, whether the individual wished to exercise it. If the answer is no, a waiver would be found. If no special circumstances existed - and that is the norm - a waiver presumably would be implied from the individual's very failure to ask or to act to invoke the right.

It has been decided that even where an individual has voluntarily begun giving potentially incriminating evidence, he has not waived his right to cease furnishing evidence and to invoke his right to counsel: $R$. v. Evans. ${ }^{86}$ In that case, the individual blew once into a breathalyzer, then asked to call a lawyer. The police response that it was too late to call a lawyer was held to be a Charter violation, as the individual had not waived his right. Here too there are contrary decisions, for example, the Ontario Court of Appeal's decision in Tremblay, ${ }^{87}$ where a request to see if counsel had arrived at a police detachment was denied and no Charter violation was found.

The recent Supreme Court of Canada decision in Clarkson appears to state a new test for waiver. As noted, Wilson J. speaking for the majority imposed a "knowledge of the consequences" test for whether a valid waiver exists when an individual was intoxicated. In Clarkson, the intoxicated individual nodded to police when read her s. 10(b) rights, then acquiesced to police questioning. Implored by a friend to stop answering questions, the individual responded there was "no point" and that she did not need a lawyer.

Wilson J. said the individual's assertions "could not possibly be taken seriously by the police as a true waiver." ${ }^{88}$

"Rather, the actions of the police in interrogating the intoxicated appellant seem clearly to have been aimed at extracting a confession which they feared they might not be able to get later when she sobered up and appreciated the need for counsel.".99

Wilson J. went on to say "At the very minimum it was incumbent upon the police to delay their questioning and the taking of the appellant's statement until she was in a sufficiently sober state to properly exercise her right to retain and instruct counsel or to be fully aware of the consequences of waiving this right."'90

86. (1984) 32 Sask. R. 87 (Q.B.).

87. (1986) 16 W.C.B. 453 (Ont. C.A.).

88. Supra n. 8 at 397 S.C.R.

89. Supra n. 8 at 397 S.C.R.

90. Supra n. 8 at 396 S.C.R. It is worth noting that Wilson J. follows Korpornay v. A.G. Can. (1982) 1 S.C.R. 41.at 49, that in any waiver it must be ". . . clear and unequivocal that the person is waiving the procedural safeguard and is doing so with full knowledge of the rights the procedure was enacted to protect and of the effect the waiver will have on those rights in the process." Supra n. 8 at 394-395 S.C.R. (emphasis in original). See also the Ontario Court of Appeal cases of R. v. Bryant (1984) 11 C.R.R. 219 at 237, and R. v. Heaslip (1983) 7 C.R.R. 257 at 269 , both of which state that there is a presumption against waiver. If such a presumption is applied to all waivers of s. 10(b) rights, the accused would no longer be saddled with the obligation to adduce evidence of a Charter breach; it would befall the prosecution to establish that the accused had waived the right with full knowledge of the right and of the consequences of waiving it. 
Thus "at minimum" police should have allowed the individual to sober up. The question left unanswered is whether once sober the individual could be said to have knowledge of the consequences. If that is the case, then Clarkson does not appear to have gone much farther than Nelson, which would have called the individual's intoxication in Clarkson a "special circumstance" and thereby would similarly have imposed a duty on police to secure a knowledgable waiver. It remains to be seen whether the courts will give a broader effect to Wilson J's knowledge of the consequences test.

\section{(c) When the Right is Invoked}

Miranda demands that once the right to counsel is invoked, police must let the individual talk to a lawyer of his choice, or inform the individual that he has a right to have a lawyer appointed at no cost. If the right is invoked, police cannot question the individual unless the individual himself initiates a conversation.

Under the Charter, as interpreted by the leading Anderson decision" once the right to counsel is invoked police typically need do no more than place the individual in a room with a telephone and a telephone book. That opportunity must be given without delay. A reasonable amount of time in the circumstances will be given to call a lawyer, or to call someone for the purpose of retaining counsel. It is unclear whether police must refrain from questioning while the individual is seeking counsel. ${ }^{92}$

\section{(i) Without Delay}

If the Charter right to counsel is invoked, police must confer the right "without delay." It has been held that it is not necessary to include the words "without delay" so long as the sense of the right - that in the circumstances a person detained or under arrest can exercise his right to counsel as soon as reasonably possible - is conveyed in a way the person can understand: $R$. v. Dombrowski. ${ }^{93}$ Moreover, the right to retain and instruct counsel without delay is not violated by a failure to be informed that the right is to be given without delay in the absence of evidence of delay: $R$. v. McLure. ${ }^{94}$

The without delay provision means that the first reasonable opportunity that is available should be given the individual who is detained or arrested.

91. Supra n. 61. See also the Alberta Court of Appeal decisions in Rogal, supra n. 85 and Williams, supra n. 82.

92. The right to counsel confers the right to seek and consult counsel through an agent: $R$. v. Keller (1984) 37 Sask. R. 94 (Q.B.), where the individual contacted his parole officer. As well, in $R$. v. Leemhuis (1985) 11 C.R.R. 337 (B.C. Co. Ct.) the Charter was violated when police refused to allow a non-lawyer friend of the accused convey advice the friend had received from a lawyer at the prior request of the accused.

However, the purpose of the agency seems limited to contacting counsel: $R$. v. Laferriere (Oct. 3, 1986 Lawyers Weekly p. 6). In R. v. Saltel (summarized Lawyers Weekly Digest Sept. $12,1986)$ the accused contacted his father to receive advice; it was held he had no right to do so. In R. v. Panchyshyn (1985) 38 Sask. R. 239 (Sask. C.A.) it was held that an accused failed to exercise his right in a bona fide manner when he called his father to ask that counsel be contacted.

93. (1985) 37 Sask. R. 259 (Sask. C.A.).

94. (1984) 25 M.V.R. 105 at 107 (B.C.C.A.). 
In Dombrowski, the Charter was violated when police refused to allow an individual to use a telephone immediately at hand, and instead insisted he could only call counsel from the police detachment. However, an individual who voluntarily waited to make a telephone call from the police station - even though a phone was available sooner - could not claim his right to counsel was breached: $R$. v. Sorokan.95

A slightly different test was put forward in $R$. v. Raffai ${ }^{96}$ in which the court stated that "without delay" was found somewhere between "immediately" and "as soon as is practicable." At the very least it meant "before [a person] did anything or said anything which might, in any way and to any degree, alter his position under the law from what his legal position was at the instance of his arrest or detention."97

\section{(ii) Time Allowed}

It is unclear how long, absent some urgency, the individual will have to retain and instruct counsel. Miranda imposes no actual time limit: this is a result of the fact that Miranda confers an affirmative right to silence. Thus even if the individual under Miranda fails to contact counsel or waives that right, he must still expressly waive the right to silence before any questioning may be attempted.

As noted, the Charter right to counsel does not include an affirmative right to silence. The police have no duty to inform the individual that he has the right to silence nor to ensure that the individual knowingly waives his right to silence. If the right to silence is invoked, police certainly must refrain indefinitely from all questioning. If however the right to silence is not invoked, it is as if it did not exist. In such a case police need only deal with the right to counsel. And the right to counsel - unlike the right to silence - appears not to be absolute: it provides that police refrain from questioning only until the individual has had a "reasonable opportunity" to retain and instruct counsel. Thus it would appear that after a "reasonable opportunity" is provided police can freely cut off the right to counsel and question the individual.

This would appear to be the implication of the court in $R$. v. Manninen.98 In finding a right to counsel violation in part because a telephone was never offered, the court went on to suggest that "different considerations might

95. (1985) 39 Sask. R. 239 (Sask. C.A.).

96. (1983) 20 M.V.R. 212 (Sask. Prov. Ct.).

97. Supra n. 96 at 216 . It is worth noting that this test has been applied implicitly to refuse exclusion of evidence after a 'technical' violation of the Charter when the individual has not prejudiced his position as a result of the delay.

98. (1984) 8 C.C.C. (3d) 193, 3 D.L.R. (4th) 541,43 O.R. (2d) 731 , 37 C.R. (3d) 162,1 O.A.C. 199, 8 C.R.R. 159, leave to appeal to the Supreme Court of Canada granted 9 C.R.R. 15n, 55 N.R. 241n). 
apply"99 if the individual refused to call a lawyer. The court made no attempt to spell out those "different considerations."

\section{(iii) Right Not to be Questioned}

The Ontario Court of Appeal in Manninen stated that police must refrain from all questioning while the individual is exercising his reasonable opportunity to contact counsel. In this respect Manninen confers substantially the same right conferred in Miranda. ${ }^{101}$

A seemingly contrary authority to Manninen exists in $R$. v. Ferguson, ${ }^{102}$ in which incriminating statements were taken from an individual after he

99. Supra n. 98 at 171 C.R.

100. The situation is totally different where there is some urgency to limit the right to counsel. The typical situation - an impaired driving investigation - will see a restriction imposed because of the two-hour limit within which police must secure breathalyzer samples. Typically police will allow a half hour for attempts at consultation, as in $R$. v. Naugler (1986) 16 W.C.B. 289 (N.S.C.A.). See also R. v. Elefante (1986) 72 A.R. 162 (Alta. C.A.) and R. v. Falk (1986) 70 A.R. 74 (Alta. C.A.). Less than 10 or 15 minutes, in the absence of some urgency, would typically be insufficient: $R$. v. Ingeberg (1985) 14 W.C.B. 339 (B.C. Co. Ct.). Police have no authority to set arbitrary time limits, but must confer a reasonable amount of time in the circumstances: $R$. v. Lamb (1984) 41 Sask. R. 284 (Q.B.). In extreme cases, Canadian courts will disregard the two-hour breathalyzer limit: Naughler (supra); Brownridge v. The Queen (1972) 7 C.C.C. (2d) 417, 28 D.L.R. (3d) 1, [1972] S.C.R. 926. But police do not have to wait indefinitely because an accused refuses to contact other than a specific lawyer: $R$. $v$. Stawnichy (unreported, 6 Nov. 1985 affg. (1984) 38 Atla. L.R. (2d) 315 (Q.B.); see also $R$. v. Merz (1985) 38 Sask. R. 32, 32 M.V.R. 227 (Q.B.); R. v. Mackie (1985) 15 W.C.B. 306 (N.S. Co. Ct.).

101. Manninen was followed on this point in United States of America v. Rennie (1984) 54 A.R. 321 (Q.B.), R. v. Nikiforuk (1986) 68 A.R. 246 (Q.B.), and R. v. Gillespie (1986) 17 W.C.B. 383, 8 C.R.D. 825.60-01. It is worth also taking note of a recently-decided Ontario Supreme Court decision, $R$. v. Grieg (The Lawyers Weekly Feb. 20, 1987, p. 1) which appears to follow the Manninen line of authority. In the cae, the individual refused to speak without counsel but police persisted questioning him. DuPont $J$. appeared to make two exceptions to the rule which also are found in Gillespie: if police conduct resulted from inadvertence or from an emergency situation. "Should police wish to interrogate the accused - who to the knowledge of the police had retained counsel - they should provide counsel with reasonable notice of their intention to do so,' DuPont J. is quoted as stating.

102. (1985) 20 C.C.C. (3d) 256 (Ont. C.A.) It is worth noting that Hetherington J.A. in Williams, supra n. 82, doubts whether Manninen guarantees a right not to be questioned. Hetherington J.A. finds some support in obiter for the right in Anderson, supra $\mathrm{n} .61$ and Esposito, supra n. 18. She also finds support for the absence of the right in the ratio of Ferguson, supra $\mathbf{n} .102$ and White, infra n. 103. Hetherington J.A. however does not address herself to the two Alberta Queen's Bench decisions which follow Manninen on the inadmissability of statements in response to questioning once the right to counsel has been invoked (see $R$. v. Nikiforuk and United States of America v. Rennie, supra n. 101.

Laycraft C.J.A. and Haddad J.A., the majority in Williams, state clearly but without discussing any cases that once the right to counsel is invoked, the individual must be given a reasonable time to secure counsel before police begin questioning. This would appear to amount to the same test as in Manninen.

The Alberta Court of Appeal will be faced with a similar issue when it hears the anticipated appeal of Wachowich J's decision in $R$. v. Brydges (unreported judgment January 20, 1987). In Brydges it was held that police improperly interrogated an individual without securing a valid waiver of the right to counsel. Another useful case with similar facts is $R$. v. Barbon (Lawyers Weekly Digest January 30, 1987 (B.C.C.A.) where the individual's initial attempts to call his lawyer failed because the lawyer was on another telephone line. A comment to that effect to police was held not to be a waiver of the individual's desire to retain counsel. The individual's answers to police questioning thereafter were ruled inadmissable as he had not waived his right.

Finally, see M.D. Bowman, "The Right to Counsel During Custodial Interrogation: Equivocal References to an Attorney - Determining What Statements or Conduct Should Constitute An Accused's Invocation of the Right to Counsel,' 39 Vand. L.R. 1159 (1986). 
invoked his s. 10(b) right. Four hours after he invoked the right, and before he had talked to counsel, a conversation with police officers led to an incriminating statement. The case appears to deny the right against being questioned once the right to counsel is invoked. Unfortunately, in Ferguson it is not clear who initiated the conversation. The American case of Edwards v. Arizona held that only the individual - and not the police could initiate a conversation once the right to counsel was invoked. In any event, Lacourciere J.A. in Ferguson distinguished Manninen as a case where the individual was denied the right to counsel from the beginning. In Ferguson, the right had been conferred, but before it was exercised fully police spoke with the individual and obtained incriminating evidence. Lacourciere J.A. stated that "A suspect who has been made aware of his constitutional rights under the Charter is, of course, free to remain silent but is also free to talk if he thinks that it will serve his purpose to do so."103

\section{(iv) Right to Presence of Counsel}

Miranda stipulates that if the right to counsel is invoked, counsel must be present during any subsequent questioning that is agreed to.

No such right exists under s. 10(b) of the Charter.

In White v. The Queen, ${ }^{104}$ counsel was present at the police detachment but was denied an opportunity to speak with the individual and was denied access to the breathalyzer room. In White the individual had spoken with his lawyer for 15 minutes on the telephone before his counsel actually arrived at the police detachment. None of the denials amounted to s. 10(b) violations. ${ }^{\text {105 }}$

Notably, one case, Crossman v. The Queen ${ }^{106}$ confers the right to the presence of counsel. Walsh J. held that s. 10(b) was violated when police, aware that an accused's counsel was coming to the detachment, began questioning the accused. There was no urgency to so question. The Charter

103. Supra n. 102 at 259. Another decision running counter to Manninen is $R$. v. White (1985) 15 W.C.B. 377 (B.C.C.A.) where the individual insisted he wanted to consult a lawyer but said he did not know one. He did not avail himself of an of fered telephone book. Police said duty counsel would be available in court in the morning. It was unclear whether any urgency existed that would have prompted a police interrogation. Indeed, the offer of duty counsel suggested the police knew the individual still wanted to consult a lawyer. Following Manninen, and in the absence of urgency, the police should have refrained from questioning. But the police in White did question the individual, and received incriminating statements. No Charter violation was found.

A similar case is $R$. v. Tremblay, supra n. 87, where police refused to interrupt breathalyzer tests when an individual asked to see if a lawyer he was expecting to call back had indeed called. Although it was found as a fact that there was no urgency, police denied his request. No Charter violation was found.

Finally, in $R$. v. Spearman (1982-83) 8 W.C.B. 364 (B.C.C.A.) the individual invoked the right to counsel, then answered questions despite the fact he knew he did not have to. The individual, who had a criminal record, was found to be accustomed to police interrogation. By responding to questions he was found in effect to have waived his right to counsel. This is contrary to the rule in Manninen that answers to questions by police should not imply a waiver of a previously-invoked right to counsel. Nevertheless in Spearman there was no Charter violation.

104. (1984) 27 M.V.R. 61,64 N.S.R. 419 (N.S. Co. Ct.).

105. See also R. v. Weber (1982-83) 8 W.C.B. 502 (Sask. Q.B.).

106. Supra n. 79. 
was further violated when counsel arrived 23 minutes later only to be denied access to the accused, who was still being questioned.

\section{Analysis}

The lengthy survey of cases points to several singular weaknesses in the Charter right to counsel compared to Miranda. But the fundamental weaknesses of the Charter right are shortcomings that also afflict Miranda. They are two-fold: under both the Charter and Miranda the individual is not adequately informed of his rights, nor of the consequences of waiving those rights.

\section{(a) Being Informed of the Right}

The whole doctrine of "special circumstances" from Nelson implies that an individual, once read the words of s. 10(b) of the Charter, without more understands the nature of the right, why he would want to exercise it and how he would go about exercising it. In what is submitted to be a giant leap of faith, the courts have said that only in special circumstances is it necessary to inform an individual further of the nature of the right to counsel, or to remind him of the right. ${ }^{107}$

The court in Manninen appeared to disapprove of the "special circumstances" doctrine. MacKinnon A.C.J.O. stated clearly that ". . . the fact that the appellant is not a young innocent, confused and frightened by the criminal process ... is irrelevant to his rights. Everyone has been guaranteed the Charter rights ... Neither the courts nor the police officers have the right to pick and choose upon whom these rights may be conferred." 108

As noted, the Ontario District Court in Menzies used Clarkson similarly to reject the "special circumstances" doctrine and to impose some unspecified uniform duty on police to ensure the individual waives his right only if he has knowledge of the consequences of doing so. It is far from clear, however, that Clarkson goes this far. One major weakness in Menzies is the assumption that Wilson J's knowledge of the consequences test applies to anyone other than an intoxicated individual. In fact, Wilson J. may well have said in Clarkson that it was intoxication alone that prevented the individual from having the requisite knowledge of the consequences. ${ }^{109}$

107. No Canadian studies exist to show whether individuals arrested or detained and advised of their right to counsel really understand the meaning of the right. Various American studies, however, confirm that most individuals do not understand the importance of the right. For example, C. Ayling, "Corroborating Confessions" (1984) Wisc. L. Rev., 1121, has pointed out that most individuals - even sophisticated ones - do not comprehend the right against self-incrimination which is ensured by the right to counsel, or the consequences of waiving that right by talking to police. In one study of Yale University faculty, staff and students, a majority showed a fundamental lack of understanding of the legal implications of a waiver of the right to counsel (at 1197).

“. . . whatever the suspects" understanding of their general legal rights in the abstract, suspects generally fail to grasp the practical effect and application of those rights in specific circumstances"' (at 1196) Ayling goes on to distinguish between "cognitive knowledge of the general rules," and "appreciation of the application and effect of those legal rules in specific circumstances."

108. Supra n. 98 at 173.

109. Clarkson was interpreted as applying only to intoxicated individuals in Moore v. $R$. (unreported, September 22, 1986, P.E.I.S.C. \#GDC 6323, Campbell J.). 
Thus no burden would be imposed on the police except to allow the individual to sober up.

Furthermore, it is far from clear that it would be desirable - as Menzies proposes and as the Alberta Court of Appeal suggests (with varying degrees of intensity) in Williams - to impose further duties on the police. The court in Nelson was very likely correct in refusing to burden the police uniformly with the duty of communicating and explaining the right. Several commentators have noted the anomaly in both the Charter right to counsel and Miranda of imposing a duty on the police - agents of the state with a vested interest in one side of the adversary system - to ensure the individual suspected of or charged with an offense is informed of his rights against self-incrimination. ${ }^{110}$

One observer has noted the obvious: ${ }^{11}$

A police officer who is anxious to obtain a statement, with frequently effective means at his disposal and with the noblest of motivations related to the 'protection of society', is likely to go a long way toward ensuring that any warning given will not be effective.

It is submitted that police cannot be relied upon to inform an individual truly of his right to counsel. Some neutral communicative mechanism is required, and it is submitted that only counsel itself available in the police detachment around the clock would be effective in conferring the right to be informed. ${ }^{112}$

\section{(b) When the Right is Waived}

Counsel at the police detachment would also ensure that an individual did not waive his right without being informed of the consequences of doing so. Observors of Miranda have long blamed inadequate waiver provisions for the continuing high rate of confessions. ${ }^{113}$ All of the glorious Miranda rights were hinged on the ability of the uncounselled individual in the coercive environment to make a "knowing and intelligent" waiver of the rights. And the definition of "knowing and intelligent" became whether the individual minimally knew what he was doing, rather than whether he extensively realized the consequences of his act.

110. See generally, Ratushny, supra nn. 16, 21; M. Manning, Rights, Freedoms and the Courts (1983); Y. Kamisar Police Interrogation and Confessions (1980), S. Ingber, "Procedure, Ceremony and Rhetoric: The Minimization of Ideological Conflict in Deviance Control," 56 Boston U.L. Rev. 266 at 280-284 (1976); Canadian Civil Liberties Association, Supra n. 20.

111. Ratushny, supra n. 16 at 347.

112. The Ontario Legal Aid Plan provides 24-hour duty counsel by telephone in metropolitan Toronto. However, the service is limited to telephone consultation, and is available only if an individual chooses to call. Source: A. John Zado, Senior Criminal Counsel, Office of the Area Director, York County, Ontario Legal Aid Plan, correspondence August 28, 1986.

113. Supra n. 110; also see generally, Y, Kamisar "Miranda: The Case, The Man, and The Players" 82 Michigan L. Rev. 1074 at 1077 (1983-84); Liva Baker, Miranda: Crime, Law and Politics (1983) 407. See also C. Ayling, supra n. 107 at 1194 for list of empirical studies showing that confessions have not decreased under Miranda.

Finally, see also S.A. Salzburg, "Miranda v. Arizona Revisted: Constitutional Law of Judicial Fiat?" 26 Washburn L.J. 1 (1986) at 21-22: "Had the Miranda court ruled that before interrogation a suspect must be warned of his rights by a magistrate and asked whether he wishes to waive them, Miranda waivers almost certainly would be unusual rather than common." 
As one critic has noted, victims of door-to-door salesmen are conferred greater rights than individuals facing waiver in police detachments: ${ }^{114}$

Rational people do not condemn themselves advisedly in the stationhouse. Recognizing that people inprudently err in far slighter matters under far slighter pressure, we now allow the targets of door-to-door salesmen a few days of tranquil reconsideration before holding them to the purchase of a vacuum cleaner.

Like Miranda, Canadian cases have generally failed to account for the uninformed waiver. Yet Clarkson - if pushed to the limit - could itself be interpreted as dictating the need for stationhouse counsel. It is interesting to note that Wilson J. in Clarkson did not discuss the Miranda test of waiver ("knowingly and intelligent"), but instead discussed a case decided one year after Miranda which itself did not discuss Miranda. Moreover, Wilson J. represented that that case - Minor v. United States ${ }^{115}$ represented American law. What she did not point out was that the issue of waiver in Minor was the subject of a dissenting judgment; the majority in Minor did not even deal with the waiver issue. Wilson J. nonetheless found support in Minor for a test of a valid waiver which included not only "knowledge and intelligence" but also a "full understanding of the implications". ${ }^{116}$ Wilson J. also discussed Von Moltke v. Gilles 117 which stated that "full understanding" included an apprehension of the specific offense, the possible defenses and the potential penalties.

Wilson J's excursion into American case law was clearly obiter in Clarkson. Nevertheless were Clarkson tilted toward the Minor and Von Moltke views it would well be interpreted as conferring a right to have counsel inform the individual of the full consequences of waiver, including apprehension of the specific offense, the possible defenses and the potential penalties. Obviously no such burden to inform could be put on police, but would fall upon a neutral third party - counsel.

\section{(c) When the Right is Invoked}

Whatever its weaknesses, where Miranda shines is in conferring rights upon the individual who has the presence of mind to invoke the right in the first place. The Miranda right includes the right to have a lawyer appointed and the right to have a lawyer present. Police are restrained from speaking to the individual at least until a lawyer is present. ${ }^{118}$ And by virtue of the right to silence is effectively no time limit imposed on reaching counsel.

Under the Charter, the right to counsel, once invoked, is a virtual parody of Miranda: it amounts to little more than being shown to a telephone, albeit shown to a telephone "without delay." This state of affairs would obviously be remedied by the provision of counsel.

With respect to the other weaknesses in the current Charter right to counsel, it is obvious that the expanded rights to be informed of the right to

114. M. E. Frankel, “From Private Fights Toward Public Justice”, 51 N.Y.U.L. Rev. 516 at 528 (Alberta's Direct Sales Cancellation Act, RSA 1980 c. D-35, s. 6 - confers the same right, allowing four days' reconsideration).

115. 375 F.2d 170 (1967 8th Cir.), Certiorari denied 389 U.S. 882.

116. Supra n. 115 at 179.

117. 332 U.S. 708 (1947).

118. Supran. 2 at 470. 
counsel would resolve the anomalous absence in Canada of an affirmative right to silence. Duty counsel would surely inform the individual of this right and the consequences of waiving it.

It is obvious also that the decisions in Ferguson, White and others would be precluded by the new right to be informed. As noted, those cases purported to deny the right not to be questioned by police once the individual had invoked his right to counsel. The decisions made a mockery of the right to counsel. Even the rule in the American case of Edwards, that conversation initiated by the individual would be allowed, is a contradiction. Surely by virtue of invoking the right to counsel the individual has indicated an uncertainty about the consequences of cooperating with police. Can it be said then that without counsel he can rationally decide that he does not need counsel after all? Surely the only logical rule is one which would prohibit any contact with the individual before counsel was reached.

However, once duty counsel is reached and the individual informed, what conduct would be open to police? Surely then any incriminating evidence given by the individual would be admissible against him. The confession would have changed from a possibly uninformed statement to a truly voluntary statement. ${ }^{119}$ But just as surely could the individual demand to remain silent, or demand to be questioned only in the presence of a lawyer. ${ }^{120}$

\section{(d) Practical Considerations}

The prospect of counsel staffing police detachments on a 24-hour basis or of otherwise making consultation with counsel possible (for example, by 24-hour telephone line) admittedly raises potentially huge logistical problems not the least of which is expense. However, compared to the resources dedicated by the state toward one side of the adversarial process - the prosecution - it is submitted that some relatively small expense to protect the right of the other party in the process could not strenuously be denied. ${ }^{121}$

In the normal "arrest" situation the right to consult stationhouse counsel would be relatively simple to confer. Police would be required to allow contact with counsel before attempting to question individuals. But what about the individual who is "psychologically detained" by police in his own living room? On first principles, whenever that individual stands

119. Ratushny, supra n. 21 at $265-309$, discusses alternatives to police interrogation including "judicial examination" models. Ratushny concludes however that all statements by an individual under arrest or detention to police should be inadmissable.

120. The provision of duty counsel at the police detachment would obviously not preclude the need for private or legal aid counsel. Indeed, it is likely that duty counsel would be restricted to providing information. On that information the individual could decide if he wanted a lawyer present. A legal aid lawyer would be available for an indigent individual as of right. On this point, see generally M.J. Mossman, "The Charter and the Right to Legal Aid," (1985) 1 Journal of Law and Social Policy 21, where the author makes a compelling case for the extension to Canada of the American right-to-counsel principle from Gideon v. Wainwright 372 U.S. 335 (1965) and Argersinger v. Hamlin 407 U.S. 25 (1972).

121. It is worth noting that Wilson J. in Singh v. Min, of Employment and Immigration [1985] 1 S.C.R. 177, 17 D.L.R. (4th) 422, stated (albeit in the context of s. 7 of the Charter and principles of fundamental justice) that it is doubtful whether utilitarian considerations "can constitute a justification for a limitation on the rights set out in the Charter." (at 218 S.C.R.). 
to incriminate himself he has the right not to be questioned until he has been conferred his right to counsel. Such a rule would not stop all police contact with individuals. General questioning not aimed at obtaining incriminating statements would be allowed. What would not be allowed would be the police tactic of surrepticiously obtaining incriminating statements in residential living rooms, or of inviting suspects into coercive police environments hoping all the time that the individual will cooperate in ignorance of his legal right not to.

Importantly, what also would not be allowed would be the admissibility of any incriminating statements made to police before the right to counsel had been conferred. Nor would derivative evidence obtained as a result of an inadmissible conversation be allowed as evidence against the individual. Such requirements raise the whole issue of whether a breach of a right confers an automatic remedy under s. 24 of the Charter. ${ }^{122}$ A thorough analysis of remedies under the Charter is not attempted here. It is enough to say that while it seems clear s. 24 does not currently confer an automatic right to the exclusion of evidence, the mandatory exclusion of evidence obtained prior to consultation with counsel is an integral element of the right to counsel herein proposed and cannot be denied. On first principles the right to counsel presumes that upon arrest or detention the individual cannot know or appreciate his right against self-incrimination until he has been informed of that right. Nor can such an individual waive the right without knowing the consequences of doing so. It is submitted that counsel is necessary to inform him effectively of the right, and of the implications of waiver. How then could any statements obtained before such consultation with counsel be found not to violate the Charter right?

\section{CONCLUSION}

The Miranda court correctly identified the principles underlying the right to counsel: the inviolability of individual rights and the need for fairness in the adversarial system. The court in Miranda however failed to dictate measures that would give effect to those principles. The definition of "custodial interrogation" was narrowly interpreted and allowed police to gather incriminating evidence before the Miranda warning was required. The Miranda wording was adopted mechanistically by police and it became clear that individuals never truly understood the meaning of the right to counsel. And after the warning was given, the rate of confessions was hardly affected as police relied on individuals, uncertain of their right against self-incrimination, to waive the right without true knowledge of the consequences.

Canada's Supreme Court has yet to speak clearly on any of the issues raised by the Charter right to counsel. Particularly on the purpose of the right to counsel, the court has failed to state the obvious: that the right to counsel exists to ensure the right against self-incrimination. On the mechanics of the right, Therens' pronouncement on detention was adopted by only half the court, and appears to have been interpreted restrictively by courts of appeal. The Supreme Court of Canada has yet to pronounce on

122. Supra n. 1 . 
what constitutes being informed of the right, and what constitutes being enabled to exercise it. As in Miranda the courts of appeal have mistakenly equated reciting a litany of words with truly informing the individual of his rights. And if the individual in Canada seeks to exercise his right, he is faced with a virtual parody of Miranda. Finally, a split court in Clarkson enunciated an undefined "knowledge of the consequences" test for waiver of the right to counsel the future of which is uncertain.

Canada's Chief Justice has called the Charter "a glorious chapter in the constitutional development of [this] nation." ${ }^{123}$ It is hoped that the court, when again given the opportunity to address the Charter right to counsel, will stand by its rhetorical convictions. And it is hoped that the court will speak clearly on the rights sought to be protected. In particular, it is submitted that any such consideration must address the following issues:

1. Psychological detention must be defined realistically as existing whenever police conduct themselves toward an individual in a coercive environment with the intent of gaining incriminating evidence.

2. Police of ficers must be relieved of any duty to inform individuals of their right to counsel; their only duty must be to refrain from questioning until the individual is informed of the rights underlying the right to counsel. To inform the individual, some neutral communicative mechanism is required, likely counsel stationed or available at police detachments.

3. Counsel must also be available to advise individuals fully of the consequences of waiving the right. Only after the right has been waived can statements made by the individual be admissable as evidence against the individual.

123. Dickson, C.J.C. went on to state that "The law's primary function is not to restrict or prohibit but to safeguard and protect persons, their privacies and freedoms." B. Dickson, "Remarks," (Address to the Call to the Bar Ceremony, Osgoode Hall, Toronto, 18 April 1985) [unpublished], quoted in F. Kaufman, "The Canadian Charter: A Time for Bold Spirits, Not Timorous Souls" (1986) 31 McGill L.J. 457. 